\title{
Carbon Dioxide Measurement
}

National Cancer Institute

\section{Source}

National Cancer Institute. Carbon Dioxide Measurement. NCI Thesaurus. Code C64545.

A quantitative measurement of the gas carbon dioxide present in a sample. 